\title{
Pengaruh Model Pembelajaran Dan Kemandirian Belajar Terhadap Kemampuan Berpikir Kritis IPA Siswa Kelas V SDN Di Jakarta Timur
}

\section{Tiara Rachamatika ${ }^{1, *}$, M. Syarif Sumantri ${ }^{1}$, Agung Purwanto ${ }^{1}$, Jatu Wahyu Wicaksono ${ }^{1}$, Alrahmat Arif ${ }^{1}$, Vina Iasha ${ }^{2}$}

${ }^{1}$ Program Studi Pendidikan Dasar, Universitas Negeri Jakarta, Indonesia

${ }^{2}$ SD Neger Pondok Bambu 06, Jakarta, Indonesia

*Email: tiara.rachmatika@yahoo.com

\begin{tabular}{|c|c|}
\hline Informasi Artikel & Abstrak \\
\hline $\begin{array}{l}\text { Kata kunci: } \\
\text { Model } \\
\text { pembelajaran, } \\
\text { Kemandirian } \\
\text { belajar, } \\
\text { Berfikir kritis }\end{array}$ & $\begin{array}{l}\text { Penelitian ini bertujuan untuk mengetahui sejauh mana pengaruh model } \\
\text { pembelajaran dan kemandirian belajar terhadap kemampuan berfikir kritis IPA } \\
\text { siswa kelas } \mathrm{V} \text { sekolah dasar di Jakarta Timur. Metode yang digunakan dalam } \\
\text { penelitian ini adalah metode eksperimen semu (quasi experimental design) yang } \\
\text { merupakan pengembangan dari metode eksperimen murni analisis varians } \\
\text { (ANAVA) dengan desain treatment by level } 2 \times 2 \text {. Adapun teknik dalam } \\
\text { pengumpulan data adalah dengan angket, tes, dan dokument. . Teknik } \\
\text { pengambilan sampel menggunakan purposive sampling. Terjadi interaksi antara } \\
\text { model pembelajaran dengan kemandirian belajar terhadap hasil kemampuan } \\
\text { berpikir kritis mata pelajaran IPA. Hasil pengujian anava diperoleh nilai F Fitung } \\
=5,63 \text { dan nilai kritik } F_{\text {tabel }}=3,98 \text { dengan dk }(1,68) \text { pada taraf á }=0,05 \text {. Hasil } \\
\text { ini menunjukkan bahwa } F_{h}=>F_{t}=\text { sehingga terdapat interaksi antara } \\
\text { penggunaan model pembelajaran dan kemandirian belajar dalam mempengaruhi } \\
\text { hasil keterampilan berpikir kritis pada mata pelajaran IPA. }\end{array}$ \\
\hline Disetujui: & Abstact \\
\hline Dipubikasikan: & $\begin{array}{l}\text { This study aims to determine the extent of the influence of the learning model } \\
\text { and independent learning on the critical thinking skills of science class } \mathrm{V} \\
\text { elementary school students in East Jakarta. The method used in this research is } \\
\text { quasi experimental design, which is the development of a pure experimental } \\
\text { method of analysis of variance (ANAVA) with a } 2 \times 2 \text { treatment by level design. } \\
\text { The techniques for collecting data are questionnaires, tests, and documents. The } \\
\text { sampling technique used purposive sampling. There is an interaction between the } \\
\text { learning model and independent learning on the results of critical thinking skills } \\
\text { in science subjects. Anava test results obtained value Fcount }=5.63 \text { and critical } \\
\text { value Ftable }=3.98 \text { with dk }(1.68) \text { at the level of á }=0.05 \text {. These results indicate } \\
\text { that Fh }=>\mathrm{Ft}=\text { so that there is an interaction between the use of learning models } \\
\text { and learning independence in influencing the results of critical thinking skills in } \\
\text { science subjects. }\end{array}$ \\
\hline
\end{tabular}




\section{PENDAHULUAN}

Pendidikan di era globalisasi saat ini merupakan unsur terpenting dalam pembangunan suatu bangsa, karena di dalam pendidikan dapat mencetak sumber daya manusia yang berkualitas untuk bisa mengikuti perkembangan jaman dan bersaing dengan negara-negara maju lainnya (Rachmadtullah et al., 2020). Sumber daya manusia yang tak lain adalah peserta didik merupakan inti dari generasi penerus bangsa. Generasi penerus bangsa harus memiliki dasar-dasar keilmuan yang akan menjadikan sumber daya manusia tersebut menjadi berkualitas. Namun, keberhasilan pendidikan saat ini belum diimbangi dengan peningkatan mutu pendidikan yang berarti (Sonia, 2020). hal ini terlihat dari masih rendahnya mutu pendidikan di Indonesia

Rendahnya mutu pendidikan di Indonesia antara lain terlihat pada jenjang pendidikan dasar. Menurut survei TIMSS dan PIRLS International study center 2015 menunjukkan bahwa mutu pendidikan dasar di Indonesia, khususnya pada bidang Science hanya mampu menempati peringkat 44 dari 47 negara dengan perolehan skor rata-rata Science 397 sementara perolehan skor tertinggi adalah negara singapore yaitu 590 (Noviana \& Murtiyasa, 2020). Sedangkan di bidang pendidikan yang di teliti oleh OECD dalam studi Programme for International Student Assessment (PISA) tahun 2009, menunjukkan bahwa Indonesia memiliki kemampuan pendidikan menghitung, membaca dan sains pada peringkat 60 dari 65 negara, namun pada tahun 2012, mengalami penurunan ke peringkat 64 dari 65 negara (Hawa \& Putra, 2018). Berdasarkan data tersebut dapat disimpulkan, Indonesia mengalami penurunan SDM terutama dibidang pendidikan sains. Padahal pembelajaran IPA sangat berperan penting bagi siswa Sekolah Dasar karena berkaitan dengan proses-proses alam serta kehidupan sehari-hari siswa.

Gambaran mutu pendidikan diatas menunjukkan bahwa proses pendidikan khususnya pembelajaran di kelas belum mampu mengembangkan potensi siswa secara optimal sesuai dengan tujuan pendidikan nasional. Pembelajaran di kelas belum optimal membekali kemampuan siswa dalam berpikir dan bertindak karena pembelajaran saat ini lebih cenderung berorientasi kepada teacher centered ketimbang berpusat pada siswa atau student centered (Setiawan, Rachmadtullah, et al., 2020). Saat ini kemampuan berpikir kritis merupakan salah satu tolak ukur dalam mencapai keberhasilan siswa (Azizah \& Widjajanti, 2019). lingkungan sekolah semestinya perlu dikondisikan agar siswa dapat mengembangkan kemampuan berpikir kritisnya. karena kemampuan berpikir kritis ini tidak muncul dengan sendirinya melainkan harus adanya upaya sadar yang dilakukan oleh guru dalam pembelajarannya. Dengan kata lain, siswa harus diberi pengalaman-pengalaman bermakna selama pembelajaran.

Kemampuan berpikir yang diarahkan melalui pembelajaran di sekolah dasar adalah kemampuan berpikir tingkat tinggi. Salah satu kemampuan berpikir tingkat tinggi (higher order thinking) adalah kemampuan berpikir kritis (critical thinking) (MASLAKHATIN, 2017). Kemampuan berpikir kritis merupakan kemampuan peserta didik dalam pemecahan masalah dan pengambilan keputusan (kesimpulan) dari berbagai aspek dan sudut pandang (Anugraheni, 2020). Kemampuan berpikir kritis adalah modal intelektual yang penting dimiliki oleh peserta didik jika berhadapan dengan permasalahan-permasalahan dalam 
kehidupannya sehari hari (Santi et al., 2018). Keterampilan berpikir kritis merupakan pemikiran yang disiplin dalam proses berpikir yang komprehensif. Untuk itu berpikir kritis harus dibiasakan mulai sejak SD khususnya untuk siswa kelas tinggi, karena hal itu akan berpengaruh pada daya ingat siswa dalam memahami suatu mata pelajaran.

Namun sayangnya, di Indonesia kemampuan berpikir kritis peserta didik belum dikembangkan terutama di sekolah dasar. Pada jenjang pendidikan Sekolah Dasar, kemampuan berpikir kritis dapat diintegrasikan pada mata pelajaran IPA (sains). IPA merupakan cara mencari tahu tentang alam secara sistematis untuk menguasai pengetahuan, fakta-fakta, konsep-konsep, prinsip-prinsip, proses penemuan, dan memiliki sikap ilmiah (Setiawan, 2015; Setiawan, Juniarso, et al., 2020). Dalam mempelajari sains diperlukan kemampuan atau kreativitas siswa agar dapat mempelajari sains dengan mudah. IPA banyak mempelajari tentang konsep-konsep yang berhubungan dengan kehidupan sehari-hari. Namun pembelajaran IPA bukan hanya menekankan pada banyaknya konsep-konsep IPA yang dihafal, tetapi lebih kepada bagaimana agar siswa berlatih menemukan sendiri konsep-konsep itu dan secara kreatif dapat mengaitkan konsep-konsep itu ke dalam lingkungan sekitarnya (Setiawan, Rachmadtullah, et al., 2020).

Berdasarkan penelitian dan observasi terhadap hasil belajar IPA semester I masih dibawah KKM rata-rata. Pendapat ini didukung oleh hasil penelitian. Pada penelitian-penelitian tersebut disebutkan bahwa kemampuan berpikir kritis dalam pembelajaran IPA masih rendah seperti yang disebutkan dalam penelitian analisis berpikir kritis IPA siswa kelas V SD yang dilakukan Wijayanti (Dw. Ayu Indri Wijayanti, 2015) penelitian dilakukan di SD Kaliuntu Berdasarkan analisis kemampuan berpikir kritis, diketahui kategori kemampuan berpikir kritis IPA siswa kelas V di setiap SD tempat penelitian. Selain itu, hasil wawancara yang dilakukan dengan guru kelas V SDN Pondok Kopi 08 Pagi pada hari kamis tanggal 9 November 2016, salah satu kemampuan siswa yang masih rendah yaitu kemampuan berpikir kritis. Dari daftar nilai kelas $\mathrm{V}$ SDN Pondok Kopi 08 Pagi, nilai rata-rata ulangan tengah semester (UTS) semester ganjil siswa pada mata pelajaran IPA adalah 65 dimana KKM dari mata pelajaran IPA di kelas V yaitu 70. Dari 30 siswa terdapat 10 siswa yang memperoleh nilai ulangan tengah semester dibawah KKM.

Berdasarkan penelitian-penelitian di atas ada beberapa faktor yang menyebabkan kemampuan berpikir siswa rendah yaitu Faktor yang pertama adalah kondisi fisik. Siswa tidak dapat berkonsentrasi, berpikir secara cepat, dan bereaksi terhadap respon yang ada akibat kondisi fisiknya terganggu. Kedua, motivasi. Ketiga, Kemandirian belajar siswa. Model pembelajaran yang dapat dikembangkan dalam pembelajaran di kelas dan secara teoritis mampu memfasilitasi pengembangan kemampuan pembelajar untuk mengembangkan cara berpikir siswa dan memungkinkan siswa untuk berinteraksi satu sama lain adalah model pembelajaran inkuiri terbimbing dan model pembelajaran kooperatif tipe thinkpair-share (TPS).

Model pembelajaran inkuiri terbimbing merupakan salah satu model pembelajaran yang berhubungan dengan keterampilan proses IPA yang didalamnya terdapat menyajikan masalah, hipotesis, merancang percobaan, menganalisis data, dan membuat kesimpulan (Suyono, 2012). Siswa seperti ilmuwan 
dalam menemukan suatu permasalahan yang diajukan guru. Sedangkan Model pembelajaran kooperatif memiliki beberapa tipe. Salah satu tipe model pembelajaran kooperatif yang dapat membangun cara berpikir pada diri siswa dan mendorong partisipasi mereka dalam kelas adalah model pembelajaran kooperatif tipe think-pair-share (TPS). Model pembelajaran kooperatif tipe thinkpair-share (TPS) membantu siswa mengintepretasikan ide mereka bersama dan memperbaiki pemahaman mereka (MA'RIFAH \& SUHAIMI, 2020).

Berdasarkan urain tersebut dapat diketahui bahwa pembelajaran menggunakan model pembelajaran kooperatif tipe think-pair-share (TPS) dan kemandirian belajar merupakan aspek penting dalam membentuk kemampuan berpikir kritis siswa. Oleh sebab itu, tujuan dari penelitian ini adalah untuk mengetahui pengaruh penggunaan model pembelajaran kooperatif tipe think-pair-share (TPS) dan aspek kemandirian belajar terhadap kemampuan berpikir kritis IPA siswa sekolah dasar

\section{METODE}

Tujuan dalam penelitian ini untuk mengetahui sejauh mana pengaruh model pembelajaran dan kemandirian belajar terhadap kemampuan berfikir kritis IPA siswa kelas V sekolah dasar di Jakarta Timur. Penelitian ini menggunakan metode eksperimen semu (quasi experimental design) yang merupakan pengembangan dari metode eksperimen murni analisis varians (ANAVA) dengan desain treatment by level $2 \times 2$. mempunyai kelompok kontrol namun tidak dapat sepenuhnya berfungsi untuk mengontrol variabelvariabel dari luar yang mempengaruhi pelaksanaan eksperimen Sugiyono (2013). Adapun teknik dalam pengumpulan data adalah dengan angket, tes, dan dokument. Teknik pengambilan sampel menggunakan purposive sampling.

Tabel 1 Desain Eksperimen dengan Treatment By Level 2 x 2

\begin{tabular}{cccc}
\hline & & \multicolumn{2}{c}{ Model Pembelajaran } \\
\cline { 2 - 4 } & & $\begin{array}{c}\text { guided inquiry } \\
\left(\mathrm{A}_{1}\right)\end{array}$ & $\begin{array}{c}\text { Cooperative learning } \\
\text { TPS type }\left(\mathrm{A}_{2}\right)\end{array}$ \\
\hline $\begin{array}{c}\text { Kemandirian } \\
\text { Belajar }\end{array}$ & High $\left(\mathrm{B}_{1}\right)$ & $\mathrm{A}_{1} \mathrm{~B}_{1}$ & $\mathrm{~A}_{2} \mathrm{~B}_{1}$ \\
\cline { 2 - 4 } & Low $\left(\mathrm{B}_{2}\right)$ & $\mathrm{A}_{1} \mathrm{~B}_{2}$ & $\mathrm{~A}_{2} \mathrm{~B}_{2}$ \\
\hline
\end{tabular}

\section{HASIL DAN PEMBAHASAN}

Berdasarkan data yang diperoleh dari penelitian diketahui bahwa hasil kemampuan berpikir kritis siswa yang dibelajarkan dengan menggunakan model pembelajaran inquiry terbimbing diperoleh skor tertinggi 90 , skor terendah 67 , nilai rata-rata 80,6 , nilai modus 77,5 median 77,5 varians 72,19 dan standar deviasi 8,5 . Berdasarkan nilai rata-rata diketahui 8 orang atau $26,6 \%$ berada di atas skor rata-rata dan sebanyak 12 orang atau $40 \%$ berada pada skor rata-rata hasil keterampilan proses sains dan 10 orang atau $33,3 \%$ berada di bawah skor rata-rata hasilkemampuan berpikir kritis. Untuk lebih jelasnya data tersebut dapat di lihat pada tabel 2 . 
Tabe1 2. Distribusi Frekuansi Hasil Kemampuan Berpikir Kritis Kelompok Siswa Menggunakan Model

Pembelajaran Inquiry Terbimbing

\begin{tabular}{cccc}
\hline No & Interval & $\mathbf{F}_{\text {absolut }}$ & $\mathbf{F}_{\text {relatif }}$ \\
\hline 1 & $67-71$ & 5 & $16,6 \%$ \\
2 & $72-76$ & 7 & $23,3 \%$ \\
3 & $77-81$ & 9 & $30 \%$ \\
4 & $82-86$ & 3 & $10 \%$ \\
5 & $87-91$ & 6 & $20 \%$ \\
\hline & Jumlah & 30 & $100 \%$ \\
\hline
\end{tabular}

Hasil Kemampuan Berpikir Kritis Kelompok Siswa yang Menggunakan Model Pembelajaran Kooperatif Tipe TPS

Dari data penelitian yang diperoleh deketahui bahwa skor tes hasil kemampuan berpikir kritis siswa yang dibelajarkan menggunakan model pembelajaran kooperatif tipe TPS memperoleh skor teringgi sebesar 86 dan skor terendah 71 nilai dengan nilai rata-rata sebesar 78,4 nilai modus 77,7 median 76,5 varians 70,8 dan standar deviasi 8,4. Berdasarkan nilai rata-rata diketahui bahwa 6 orang atau $20 \%$ berada di atas skor rata-rata dan sebanyak 12 orang atau 40\% berada pada skor rata-rata hasil keterampilan proses sains dan 12 orang atau $40 \%$ berada di bawah skor rata-rata hasil kemampuan berpikir kritis. Untuk lebih jelasnya data tersebut dapat dilihat pada tabel 3 .

Tabel 3. Distribusi Frekuansi Hasil Kemampuan Berpikir Kritis Kelompok Siswa Menggunakan Model

\begin{tabular}{cccc}
\multicolumn{4}{c}{ Pembelajaran Kooperaif Tipe TPS } \\
\hline No & Interval & $\mathbf{F}_{\text {absolute }}$ & $\mathbf{F}_{\text {relatif }}$ \\
\hline 1 & $71-73$ & 7 & $6,6 \%$ \\
2 & $74-76$ & 6 & $16,6 \%$ \\
3 & $77-79$ & 8 & $36,66 \%$ \\
4 & $80-82$ & 5 & $20 \%$ \\
5 & $83-85$ & 3 & 2042 \\
6 & $86-88$ & 1 & $3,33 \%$ \\
\hline & Jumlah & 30 & $100 \%$ \\
\hline
\end{tabular}

\section{Hasil Kemampuan Berpikir Kritis Siswa yang Memiliki Kemandirian Belajar Tinggi}

Dari data penelitian yang diperoleh diketahui bahwa skor tes hasil kemampuan berpikir kritis siswa yang memiliki kemandirian belajar tinggi memperoleh skor tertinggi sebesar 89, dan skor terendah 68 dengan nilai rata-rata 77,5 , nilai modus sebesar 76,5 nilai median 77,5 dan varians sebesar 70,97 , dan standar deviasi 8,4. Berdasarkan nilai rata-rata hasil kemampuan berpikir kritis diketahui 6 orang atau $20 \%$ berada pada skor diatas rata-rata hasil kemampuan berpikir kritis12 orang atau 40\% berada pada skor rata-rata hasil kemampuan berpikir kritis dan 12 orang atau 40\% berada dibawah skor rata-rata. Untuk lebih jelasnya data tersebut dapat dilihat pada tabel 4 . 
Tabel 4. Distribusi Frekuansi Hasil Kemampuan Berpikir Kritis Siswa yang Memiliki Kemandirian Belajar Tinggi

\begin{tabular}{cccc}
\hline No & Interval & $\mathbf{F}_{\text {absolut }}$ & $\mathbf{F}_{\text {relatif }}$ \\
\hline 1 & $68-72$ & 5 & $16,6 \%$ \\
2 & $73-77$ & 9 & $30 \%$ \\
3 & $78-82$ & 8 & $26,6 \%$ \\
4 & $83-87$ & 4 & $13,3 \%$ \\
5 & $88-92$ & 4 & $13,3 \%$ \\
\hline & Jumlah & 30 & $100 \%$ \\
\hline
\end{tabular}

\section{Hasil Kemampuan Berpikir Kritis Kelompok Siswa yang Memiliki Kemandirian Belajar Rendah}

Dari data penelitian yang diperoleh bahwa skor tes hasil kemampuan berpikir kritis siswa yang memiliki kemandirian belajar rendah memperoleh skor tertinggi 90 , skor terendah 65 , dengan perolehan nilai rata-rata sebesar 74,76, nilai modus 78 , median 75,5 , varians 70 dan standar deviasi 8,3 . Berdasarkan nilai rata-rata diketahui 11 orang atau 36,6\% berada pada skor rata-rata hasilkemampuan berpikir kritis, sebanyak 5 orang atau 16,6\% berada di atas skor rata-rata hasil kemampuan berpikir kritis dan sebanyak 14 orang atau 46,66\% berada di bawah rata-rata skor hasil kemampuan berpikir kritis. Untuk lebih jelasnya data tersebut dapat dilihat pada tabel 5 .

Tabel 5. Distribusi Frekuansi Hasil Kemampuan Berpikir Kritis Kelompok Siswa yang Memiliki Kemandirian Belajar Rendah

\begin{tabular}{cccc}
\hline No & Interval & $\mathbf{F}_{\text {absolut }}$ & $\mathbf{F}_{\text {relatif }}$ \\
\hline 1 & $65-68$ & 5 & $16,6 \%$ \\
\hline 2 & $69-72$ & 6 & $20 \%$ \\
\hline 3 & $73-76$ & 5 & $16,6 \%$ \\
\hline 4 & $77-80$ & 8 & $26,6 \%$ \\
\hline 5 & $81-84$ & 3 & $10 \%$ \\
\hline 6 & $85-88$ & 2 & $6,6 \%$ \\
\hline 7 & $89-90$ & 1 & $3,3 \%$ \\
\hline & Jumlah & 30 & $100 \%$ \\
\hline
\end{tabular}

\section{Hasil Kemampuan Berpikir Kritis Siswa untuk Kemandirian Belajar Tinggi yang Diajar Menggunakan Model Pembelajaran Inquiry Terbimbing}

Dari data penelitian yang diperoleh bahwa skor tes hasil kemampuan berpikir kritis untuk kemandirian belajar tinggi yang diajar menggunakan model pembelajaran inquiry terbimbing memperoleh skor tertinggi 95 , skor terendah 70, dengan nilai rata-rata adalah 83,66, nilai modus sebesar 77,5, median 79,5 varians 77,2 dan standar deviasi 8,7. Berdasarkan nilai rata-rata diketahui 6 orang atau $40 \%$ berada pada skor rata-rata hasil kemampuan berpikir kritis dan sebanyak 6 orang atau $40 \%$ berada di atas skor ratarata hasil kemampuan berpikir kritis pelajaran IPA dan 3 orang atau 20\% berada di bawah skor rata-rata hasilkemampuan berpikir kritis. Untuk lebih jelasnya data tersebut dapat dilihat pada tabel 6. 
Tabel 6. Distribusi Frekuansi Hasil Kemampuan Berpikir Kritis Siswa Untuk Kemandirian Belajar Tinggi

\begin{tabular}{cccc}
\multicolumn{4}{c}{ Menggunakan Model Pembelajaran Inquiry Terbimbing } \\
\hline $\mathbf{N o}$ & Interval & $\mathbf{F}_{\text {absolut }}$ & $\mathbf{F}_{\text {relatif }}$ \\
\hline 1 & $70-74$ & 2 & $13,3 \%$ \\
\hline 2 & $75-79$ & 5 & $33,3 \%$ \\
\hline 3 & $80-84$ & 3 & $20 \%$ \\
\hline 4 & $85-89$ & 3 & $20 \%$ \\
\hline 5 & $90-94$ & 1 & $6,6 \%$ \\
\hline 6 & $95-99$ & 1 & $6,6 \%$ \\
\hline & Jumlah & 15 & $100 \%$
\end{tabular}

\section{Hasil Kemampuan Berpikir Kritis Kelompok Siswa yang Memiliki Kemandirian Belajar Tinggi yang Diajar Menggunakan Model Pembelajaran Kooperatif Tipe TPS}

Dari data penelitian yang diperoleh bahwa skor tes hasil kemampuan berpikir kritis kelompok siswa yang memiliki kemandirian belajar tinggi yang diajar menggunakan model pembelajaran kooperatif tipe TPS memperoleh skor tertinggi 89 , skor terendah 68 , dengan nilai rata-rata adalah 80,06 , nilai modus 86,5 , median 76,5 varians 73,90 dan standar deviasi 8,5 . Berdasarkan nilai rata-rata diketahui 4 orang berada diatas skor rata-rata hasilketerampilan proses sains, 4 orang berada pada skor rata-rata hasil keterampilan proses sains dan sebanyak 7 orang berada di bawah skor rata-rata hasil keterampilan proses sains siswa mata pelajaran IPA. Untuk lebih jelasnya data tersebut dapat dilihat pada tabel 7.

Tabel 7. Distribusi Frekuensi Hasil Kemampuan Berpikir Kritis Kelompok Siswa yang Memiliki Kemandirian Belajar Tinggi yang Diajar Menggunakan Model Pembelajaran Kooperatif Tipe TPS

\begin{tabular}{cccc}
\hline $\mathbf{N o}$ & Interval & $\mathbf{F}_{\text {absolut }}$ & $\mathbf{F}_{\text {relatif }}$ \\
\hline 1 & $68-71$ & 2 & $13,3 \%$ \\
\hline 2 & $72-75$ & 3 & $20 \%$ \\
\hline 3 & $76-79$ & 3 & $20 \%$ \\
\hline 4 & $80-83$ & 4 & $26,6 \%$ \\
\hline 5 & $84-87$ & 2 & $13,3 \%$ \\
\hline 6 & $88-91$ & 1 & $6,6 \%$ \\
\hline & Jumlah & 15 & $100 \%$ \\
\hline
\end{tabular}

\section{Hasil Kemampuan Berpikir Kritis Siswa Kelompok yang Memiliki Kemandirian Belajar Rendah yang Diajar Menggunakan Model Pmebelajaran Inquiry Terbimbing}

Dari data penelitian yang diperoleh bahwa skor tes hasil kemampuan berpikir kritis kelompok yang memiliki kemandirian belajar rendah diajar menggunakan model pembelajaran inquiry terbimbing memperoleh skor tertinggi 90 , skor terendah 62 , dengan nilai rata-rata adalah 76 , nilai modus 76,5 , median 78,5 , varians 62 dan standar deviasi 7,9. Berdasarkan nilai rata-rata diketahui 3 orang berada diatas skor ratarata hasil kemampuan berpikir kritis, 7 orang berada pada skor rata-rata hasil hasil kemampuan berpikir kritis dan sebanyak 5 orang berada di bawah skor rata-rata hasil kemampuan berpikir kritis pada pelajaran IPA. Untuk lebih jelasnya data tersebut dapat dilihat pada tabel 8. 
Tabel 8. Distribusi Frekuensi Hasil Kemampuan Berpikir Kritis Kelompok Siswa yang Memiliki Kemandirian Belajar Rendah Diajar Menggunakan Model Pembelajaran Inquiry Terbimbing

\begin{tabular}{cccc}
\hline No & Interval & $\mathbf{F}_{\text {absolut }}$ & $\mathbf{F}_{\text {relatif }}$ \\
\hline 1 & $62-67$ & 1 & $6,6 \%$ \\
\hline 2 & $68-73$ & 3 & $20 \%$ \\
\hline 3 & $74-79$ & 7 & $23 \%$ \\
\hline 4 & $80-85$ & 3 & $20 \%$ \\
\hline 5 & $86-90$ & 1 & $6,6 \%$ \\
\hline & Jumlah & 15 & $100 \%$ \\
\hline
\end{tabular}

\section{Hasil Kemampuan Berpikir Kritis Siswa untuk Kelompok yang Memiliki Kemandirian Belajar Rendah yang Diajar Menggunakan Model Pembelajaran Kooperatif Tipe TPS}

Dari data penelitian yang diperoleh bahwa skor tes hasil keterampilan kemampuan berpikir kritis kelompok siswa memiliki kemandirian belajar rendah yang diajar menggunakan model pembelajaran kooperatif tipe TPS memperoleh skor tertinggi 91, skor terendah 70, dengan nilai rata-rata adalah 78,26, nilai modus 79,5, median 77,5, varians 77 dan standar deviasi 8,7. Berdasarkan nilai rata-rata diketahui 4 orang berada diatas skor rata-rata hasilkemampuan berpikir kritis, 7 orang berada pada skor rata-rata hasil kemampuan berpikir kritis dan sebanyak 4 orang berada di bawah skor rata-rata hasil kemampuan berpikir kritis pada mata pelajaran IPA. Untuk lebih jelasnya data tersebut dapat dilihat pada tabel 9.

Tabel 9. Distribusi Frekuansi Hasil Kemampuan Berpikir Kritis Kelompok Siswa yang Memiliki Kemandirian Belajar Rendah yang Diajar Menggunakan Model Pembelajaran Kooperatif Tipe TPS

\begin{tabular}{cccc}
\hline No & Interval & $\mathbf{F}_{\text {absolut }}$ & $\mathbf{F}_{\text {relatif }}$ \\
\hline 1 & $70-73$ & 4 & $26 \%$ \\
\hline 2 & $74-77$ & 1 & $6,6 \%$ \\
\hline 3 & $78-81$ & 5 & $33,3 \%$ \\
\hline 4 & $82-85$ & 1 & $66 \%$ \\
\hline 5 & $86-89$ & 5 & $33,3 \%$ \\
\hline 6 & $90-93$ & 1 & $66 \%$ \\
\hline & Jumlah & 15 & $100 \%$ \\
\hline
\end{tabular}

Karena ada interaksi antara model pembelajaran dan kemandirian belajar siswa dalam mempengaruhi hasilkemampuan berpikir kritis maka perlu dilakukan uji lanjutan, untuk mengetahui rata-rata hasil kemampuan berpikir kritis sampel mana yang berbeda. Untuk melihat bentuk interaksi antara model pembelajaran dan kemandirian belajar dalam mempengaruhi hasil kemampuan berpikir kritis siswa dilakukan uji lanjut dengan menggunakan Uji Scheffe, hasil perhitungan menggunakan Uji Scheffe dapat dikemukakan melalui ringkasan pada tabel 10.

Tabel 11. Ringkasan Hasil Perhitungan Uji Scheffe

\begin{tabular}{cccc}
\hline No & Interaksi & $\mathbf{F}_{\text {hitung }}$ & $\mathbf{F}_{\text {tabel }(\dot{\mathbf{a}}=\mathbf{0 , 0 5})}$ \\
\hline 1 & $\mu \mathrm{A} 1 \mathrm{~B} 1$ dengan $\mu \mathrm{A} 2 \mathrm{~B} 1$ & 3,230 & 2,750 \\
\hline 2 & $\mu \mathrm{A} 1 \mathrm{~B} 1$ dengan $\mu \mathrm{A} 2 \mathrm{~B} 2$ & 3,260 & 2,750 \\
\hline 3 & $\mu$ A1B1 dengan $\mu$ A1B2 & 3,240 & 2,750 \\
\hline 4 & $\mu$ A1B2 dengan $\mu$ A2B1 & 0,070 & 2,750 \\
\hline 5 & $\mu$ A1B2 dengan $\mu$ A2B2 & 0,301 & 2,750 \\
\hline 6 & $\mu$ A2B2 dengan $\mu$ A2B1 & 0,350 & 2,750 \\
\hline
\end{tabular}


Kriteria penerimaan jika Fhitung $>$ Ftabel maka teruji secara signifikan. Berdasarkan hasil uji scheffe pada tabel di atas dapat dilihat bahwa terdapat 6 (enam) pasang hipotesis statistik, yakni:

a. Dari hasil perhitungan dengan menggunakan uji scheffe pada tabel di atas rnenunjukkan $F_{\text {hitung }}=3,230$ $>\mathrm{F}_{\text {tabel }}=2,750$, sehinga memberikan keputusan menolak hipotesis nol (Ho) dan hipotesis alternatif (Ha) diterima. Dengan demikian hipotesis penelitian yang menyatakan bahwa ada perbedaan hasil hasil kemampuan berpikir kritis siswa pada mata pelajaran IPA jika diajar menggunakan model inquiri terbimbing kelompok siswa yang memiliki kemandirian belajar tinggi dengan pembelajaran kooperatif tipe TPS kelompok siswa memiliki kemandirian belajar tinggi teruji kebenarannya.

b. Dari hasil perhitungan dengan menggunakan uji scheffe pada tabel di atas rnenunjukkan $\mathrm{F}_{\text {hitung }}=3,260$ $>\mathrm{F}_{\text {tabel }}=2,750$, sehinga memberikan keputusan menolak hipotesis nol (Ho) dan hipotesis alternatif (Ha) diterima. Dengan demikian hipotesis penelitian yang menyatakan bahwa ada perbedaan hasil kemampuan berpikir kritis siswa pada mata pelajaran IPA jika diajar menggunakan inquiri terbimbing kelompok siswa yang memiliki kemandirian belajar tinggi dengan pembelajaran kooperatif tipe TPS kelompok siswa memiliki kemandirian belajar rendah teruji kebenarannya.

c. Dari hasil perhitungan dengan menggunakan uji scheffe pada tabel di atas rnenunjukkan $F_{\text {hitung }}=3,040$ $>\mathrm{F}_{\text {tabel }}=2,750$, sehinga memberikan keputusan menolak hipotesis nol (Ho) dan hipotesis alternatif (Ha) diterima. Dengan demikian hipotesis penelitian yang menyatakan bahwa ada perbedaan hasil kemampuan berpikir kritis siswa pada mata pelajaran IPA jika diajar menggunakan inquiry terbimbing kelompok siswa yang memiliki kemandirian belajar tinggi dan kelompok siswa memiliki kemandirian belajar rendah teruji kebenarannya.

d. Dari hasil perhitungan dengan menggunakan uji scheffe pada tabel di atas rnenunjukkan $F_{\text {hitung }}=0,070$ $>\mathrm{F}_{\text {tabel }}=2,750$, sehinga memberikan keputusan menolak hipotesis nol (Ho) dan hipotesis alternatif (Ha) diterima. Dengan demikian hipotesis penelitian yang menyatakan bahwa ada perbedaan hasil kemampuan berpikir kritis siswa pada mata pelajaran IPA jika diajar menggunakan inquiry terbimbing kelompok siswa yang memiliki kemandirian belajar rendah dan kelompok siswa memiliki kemandirian belajar tinggi teruji kebenarannya.

e. Dari hasil perhitungan dengan menggunakan uji scheffe pada tabel di atas rnenunjukkan $F_{\text {hitung }}=0,301$ $>\mathrm{F}_{\text {tabel }}=2,750$, sehinga memberikan keputusan menolak hipotesis nol (Ho) dan hipotesis alternatif (Ha) diterima. Dengan demikian hipotesis penelitian yang menyatakan bahwa ada perbedaan hasil kemampuan berpikir kritis siswa pada mata pelajaran IPA jika diajar menggunakan inquiry terbimbing kelompok siswa yang memiliki kemandirian belajar rendah rendah dengan pembelajaran kooperatif tipe TPS kelompok siswa memiliki kemandirian belajar rendah teruji kebenarannya.

f. Dari hasil perhitungan dengan menggunakan uji scheffe pada tabel di atas rnenunjukkan $F_{\text {hitung }}=0,350$ $>\mathrm{F}_{\text {tabel }}=2,750$, sehinga memberikan keputusan menolak hipotesis nol (Ho) dan hipotesis alternatif (Ha) diterima. Dengan demikian hipotesis penelitian yang menyatakan bahwa ada perbedaan hasil 
kemampuan berpikir kritis siswa pada mata pelajaran IPA jika diajar menggunakan inquiri terbimbing kelompok siswa yang memiliki kemandirian belajar tinggi dengan pembelajaran penugasan kooperatif tipe TPS kelompok siswa memiliki kemandirian belajar rendah teruji kebenarannya

Untuk melihat dengan jelas anava yang menunjukkan interaksi antara penggunaan model pembelajaran dan kemandirian belajar siswa dalam mempengaruhi hasil kemampuan berpikir kritis siswa paada mata pelajaran IPA dapat ditunjukkan melaui gambar berikut:

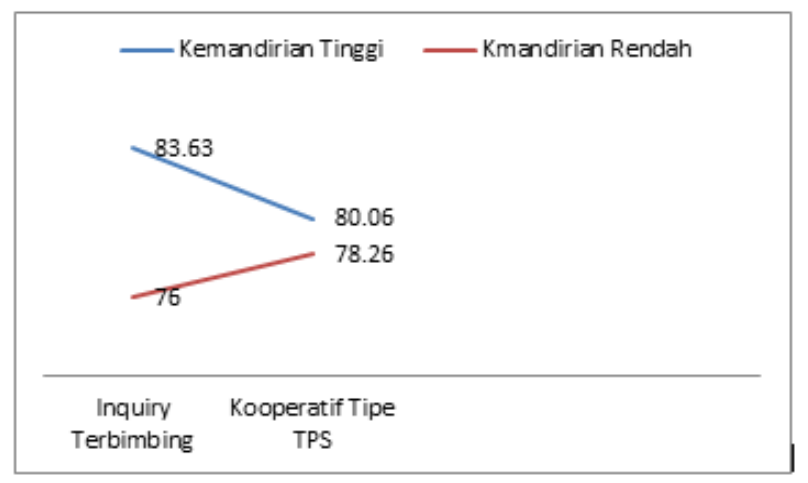

Gambar 1 Interaksi model pembelajaran dan kemandirian belajar Terhadap Hasil kemampuan berpikir kritis Pelajaran IPA

\section{KESIMPULAN}

adapun kesimpulan yang diperoleh, yakni hasil kemampuan berpikir kritis IPA siswa menggunakan inquiry terbimbing memperoleh nilai rata-rata sebesar 80,66 dan siswa yang menggunakan model kooperatif tipe TPS 78,4. Hasil kemampuan berpikir kritis siswa memiliki kemandirian belajar tinggi memperoleh rata-rata sebesar 77,5 dan siswa yang memiliki kemampuan berpikir kreatif rendah memperoleh rata-rata sebesar 74,76. Hasil kemampuan berpikir kritis kelompok siswa menggunakan model inquiry terbimbing dengan kemandirian belajar tinggi sebesar 83,66 dan siswa menggunakan model inquiri terbimbing dengan kemandirian belajar rendah memperoleh rata-rata sebesar 76,0. Hasil kemampuan berpikir kritis kelompok siswa menggunakan model kooperatif dengan kelompok kemandirian tinggi sebesar 80,6 dan siswa menggunakan penugasan konvensional dengan kemampuan berpikir kreatif rendah memperoleh rata-rata 78,2. Terjadi interaksi antara model pembelajaran dengan kemandirian belajar terhadap hasil kemampuan berpikir kritis mata pelajaran IPA. Hasil pengujian anava diperoleh nilai $F_{\text {hitung }}=5,63$ dan nilai kritik $F_{\text {tabel }}=$ 3,98 dengan dk $(1,68)$ pada taraf á $=0,05$. Hasil ini menunjukkan bahwa $F_{h}=>F_{t}=$ sehingga terdapat interaksi antara penggunaan model pembelajaran dan kemandirian belajar dalam mempengaruhi hasil keterampilan berpikir kritis pada mata pelajaran IPA.

\section{DAFTAR PUSTAKA}

Anugraheni, I. (2020). Analisis Kesulitan Mahasiswa dalam Menumbuhkan Berpikir Kritis Melalui Pemecahan Masalah. Jumal Cendekia: Jurnal Pendidikan Matematika, 4(1), 261-267.

Azizah, I. N., \& Widjajanti, D. B. (2019). Keefektifan pembelajaran berbasis proyek ditinjau dari prestasi belajar, kemampuan berpikir kritis, dan kepercayaan diri siswa. Jurnal Riset Pendidikan Matematika, 6(2), 
$233-243$.

Hawa, A. M., \& Putra, L. V. (2018). PISA untuk siswa Indonesia. Janacitta, 1(01).

Khanifatul. (2013). Pembelajaran Inovatif : Strategi Mengelola Kelas Secara Efektif dan Menyenangkan. Yogyakarta: Ar-Ruzz Media.

MA'RIFAH, L. N. U. R., \& SUHAIMI, I. (2020). THE EFFECTIVENESS OF FLASHCARDS IN TEACHING VOCABULARY FOR SEVENTH GRADE STUDENTS OF SMP WAHIDIYAH KEDIRI. Buana Pendidikan: Jurnal Fakultas Keguruan Dan Ilmu Pendidikan, 16(29 SE-), 81-91. https://doi.org/10.36456/bp.vol16.no29.a2272

MASLAKHATIN, M. (2017). CRITICAL READING STRATEGIES TO FOSTER STUDENTSâ€TM CRITICAL THINKING. Buana Pendidikan: Jurnal Fakultas Keguruan Dan Ilmu Pendidikan, 12(22 SE-), 99-110. https://doi.org/10.36456/bp.vol12.no22.a621

Noviana, K. Y., \& Murtiyasa, B. (2020). Kemampuan Literasi Matematika Berorientasi PISA Konten Quantity pada Siswa SMP. JNPM (Jurnal Nasional Pendidikan Matematika), 4(2), 195-211.

NRC. (1996). The National Science Education Standards National Science Education Standards. Washington DC: National Academy Press.

Rachmadtullah, R., Yustitia, V., Setiawan, B., Mahya Fanny, A., Pramulia, P., Susiloningsih, W., Tur Rosidah, C., Prastyo, D., \& Ardhian, T. (2020). The Challenge Of Elementary School Teachers To Encounter Superior Generation In The 4.0 Industrial Revolution: Study Literature. International Journal of Scientific \& Technology Research, 9(4), 1879-1882. www.ijstr.org

Santi, N., Soendjoto, M. A., \& Winarti, A. (2018). Kemampuan berpikir kritis mahasiswa Pendidikan Biologi melalui penyelesaian masalah lingkungan. Bioedukasi, 11(1), 35-39.

Setiawan, B. (2015). Eksperimentasi Model Pembelajaran Problem Solving dengan Pendekatan Peer Tutoring Berbasis Metode Pembelajaran Eksperimen dan Demonstrasi pada Materi Fluida Statis Siswa Kelas X MIA SMA Negeri 1 Banyudono.

Setiawan, B., Juniarso, T., Fanani, A., \& Iasha, V. (2020). Pembelajaran Online Di Masa Pandemi Covid19: Pengaruhnya Terhadap Pemahanan Konsep Fisika Mahasiswa. Jurnal Pendidikan Dasar, 11(02), 230-236.

Setiawan, B., Rachmadtullah, R., \& Iasha, V. (2020). Problem-Solving Method: The Effectiveness of The Pre-service Elementary Education Teacher Activeness in The Concept of Physics Content. Jurnal Basicedu, 4(4), 1074-1083.

Sonia, N. R. (2020). Implementasi Sistem Informasi Manajemen Pendidikan (Simdik) dalam Meningkatkan Mutu Pendidikan di Madrasah Aliyah Negeri 2 Ponorogo. Education, 1(1), 94-104.

Sugiyoo. (2011). Metode Penelitian Kuantitatif, kualitatif, dan R \& D . Jakarta: Alfabeta.

Suyono, S. (2012). PENGGUNAAN STRATEGI PEMBELAJARAN TERHADAP PRESTASI BELAJAR PKn SISWA SMPN 2 GEDANGAN SIDOARJO YANG MEMILIKI TINGKAT GAYA BELAJAR YANG BERBEDA. Buana Pendidikan: Jurnal Fakultas Keguruan Dan Ilmu Pendidikan, 8(14 SE-). https://doi.org/10.36456/bp.vol8.no14.a1208

Tirtarahardja, U., \& Sulo, L. (2005). Pengantar Pendidikan. Jakarta: Rineka Cipta.

Wijayanti, D. I. (2015). Analisis Kemampuan Berpikir Kritis Siswa Kelas V Dalam Pembelajaran IPA di 3 SD Gugus X Kecamatan Buleleng. e-Journal PGSD Universitas Pendidikan Ganesha Jurusan PGSD , 3(1). 